\title{
Duodenum/Ampulla/Jejunum/lleum Neuroendocrine Tumor pT3 TNM Finding v7
}

National Cancer Institute

\section{Source}

National Cancer Institute. Duodenum/Ampulla/Jejunum/lleum Neuroendocrine Tumor

pT3 TNM Finding v7. NCI Thesaurus. Code C90087.

Duodenum/ampulla/jejunum/ileum neuroendocrine tumor invading through the

muscularis propria into subserosal tissue without penetration of overlying serosa (jejunal or ileal tumors) or invading pancreas or retroperitoneum (ampullary or duodenal tumors) or into non-peritonealized tissues. (from AJCC 7th Ed.) 